\title{
Prevalence of rumen impaction with non-biodegrable materials in cattle
} in Ibadan, Nigeria

\author{
Akinrinmade, ${ }^{1}$ J. F. and Akinrinde, ${ }^{2}$ S. A. \\ ${ }^{1}$ Department of Veterinary Surgery and Reproduction, \\ University of Ibadan, Ibadan. \\ ${ }^{2}$ Department of Biochemistry, University of Ibadan, Ibadan.
}

\section{Abstract}

A study was conducted on 3031 cattle slaughtered in Ibadan over a period of three months to determine the prevalence of rumen impaction with indigestible garbage and evaluate breed, sex, age and some blood indices as risk factors.

Thorough antemortem and postmortern examinations were carried out on each of the animals to determine the breed, health status, sex, age and presence of indigestible garbage in the rumen while blood samples were collected and analysed only for animals with indigestible garbage, to determine total serum protein and phosphorus levels.

Results showed overall prevalence of rumen impaction was $10.77 \%$ and it differed significantly between breeds, but was highest in the Red Bororo (RB). Sex and age had significant influence on the prevalence of rumen impaction. It was significantly higher $(P<$ $0.05)$ in females than in males and in older animals than in younger ones.

Total serum protein and phosphorus levels were significantly lower than reference values in animals with rumen impaction.

Keywords - Rumen impaction, Biodegradable materials, Cattle, Prevalence

\section{Introduction}

The indigenous ruminant livestock industry in Nigeria represents a very important national resource, contributing immensely to national health and wealth through supply of protein and industrial raw materials.

A high proportion of this livestock population are reared under the extensive system of animal husbandry characterized by uncontrolled movement over a large expanse of land, grossly inadequate feed intake, poor nutrition and high disease prevalence.

Reports on the incidence of rumen impaction with indigestible garbage in cattle, sheep and goats reared under extensive system of management in Northern Nigeria had been documented (Abdullahi et al., 1984, Elsa et al., 1988, Remi-Adewumi et al., 2004). These authors incriminated inadequate availability of feed especially during the dry season as the major risk factor in the establishment of the condition. Sanni et al., (1998) however ascribed widespread use of polythene bags and lack of proper legislation on waste disposal, as major contributory factors in the aetiopathogenesis of the condition in the north.

Fatalities associated with foreign body rumen impaction in ruminants have been reported (Akinrinmade et al., 1988, Otesile and Akpokodje, 1991). Recently, it has been observed that foreign body rumen impaction associated with ingestion of nonbiodegradable materials constitutes the major indication for laparorumenotomy in cattle, sheep and goats presented to the Veterinary Teaching Hospital of the University of Ibadan. The number of cases diagnosed by exploratory laparorumenotomy is at present on the increase and a genuine cause for concern to 
clinicians. In view of the fact that the aetiopathogenesis of the condition is still poorly understood, its recognition in the subclinical phase still poses a challenge to the clinicians.

Minerals and biochemical disorders, including deficiencies toxicities and inbalances have been documented to be risk factors in the establishment of many livestock diseases (Conrad et al., 1982; McDowell 1985; Langhans and Scharret, 1986, Radostits et al., 1994). Phosphorus as a major element has more known functions in the animal body than any other mineral element. Extensive areas of phosphorus deficient soils occur throughout the world especially in tropical and sub-tropical areas such as Nigeria and a deficiency of this element is regarded as the most widespread and economically important of all the mineral disabilities affecting grazing livestock (McDonald et al., 1998). Pica or depraved appetite or abnormal appetite manifested by the chewing of wood, bones, rags and other foreign materials and poor fertility have been reported to be associated with phosphorus deficiency in cattle (McDonald et al., 1988; Radostitis et al., 1994; Grumberg et al., 2006). Similarly, Akinrinmade et al., 1988 and Otesile and Akpokodje 1991 incriminated malnutrition as a probable aetiopathogenic factor in their reports on fatal cases of rumen impaction. There is still a dearth of information on the mineral and biochemical profile of cattle with rumen impaction with indigestible garbage. The purpose of this investigation therefore is to determine the prevalence of rumen impaction with indigestible garbage in cattle slaughtered in Ibadan, Southwest Nigeria, with respect to breed, sex, age and some blood indices as risk factors.

\section{Materials and Methods}

The investigation was carried out at the central abattoir of Ibadan, a city located in the southwest tropical humid zone, along the north-south normadic route. The study which was conduced during the months of March, April and May of the year involved regular visits to the abbatoir for antemortem and post-morterm examinations of animals brought into lairage for slaughter.

Pre-slaughter physical examination was performed on each of the animals to determine their health status, sex, age and breed. Animals were also observed closely for signs of disease or pathological conditions through their general disposition, gait, condition of hair coat, faeces and visible mucous membrane. Those found to be unhealthy were held as suspects and noted for detailed post-mortern examination. Blood samples were collected at slaughter and analysed to determine levels of serum protein and phosphorus in animals with rumen impaction with indigestible garbage. With easily distinguishable colour markings, breed and sex, a systematic examination of the fore stomach, starting from the rumen, was arrived at on each of the animals immediately after flaying and evisceration. The teeth were examined in detail according to the method described by Sisson and Grossman (1975) to estimate the age of the animal. Records of all findings were collated and subjected to appropriate statistical analysis.

\section{Results}

The results of the examinations showed that a significantly high percentage $(73.5 \%)$ of the animals brought in for slaughter were in poor body condition. They were moderately to severely emaciated with prominent rib cage and pelvic bone, presence of bruises and abrasions on the skin and fairly pale 
Table - 1 Breed distribution and prevalence of rumen impaction in animals examined.

\begin{tabular}{lcc}
\hline Breed of Cattle & Number Examined (\%) & $\begin{array}{l}\text { Number with } \\
\text { Rumen } \\
\text { Impaction (\%) }\end{array}$ \\
\hline Kuri & $244(8.0)$ & $15(0.49)$ \\
Red Bororo & $772(25.50)$ & $213(7.03)$ \\
White Fulani & $816(26.90)$ & $26(0.85)$ \\
Sokoto Gudali & $971(32.20)$ & $54(1.78)$ \\
Azawak & $91(3.00)$ & $8(0.26)$ \\
Keteku & $139(4.60)$ & $11(0.36)^{*}$ \\
Total & $\mathbf{3 0 3 1}(\mathbf{1 0 0})$ & $\mathbf{3 2 7 ( 1 0 . 7 7 )}$ \\
\hline
\end{tabular}

carcass. The breed distribution and prevalence of rumen impaction with non biodegradable materials is shown in Table 1. Out of the 3031 animals examined, Sokoto Gudali (SG) was the most common of the 6 different breeds encountered while Azawak (AZ) was the least slaughtered with $32.0 \%$ and $3.00 \%$ respectively.

The overall prevalence of rumen impaction with non- biodegradable materials in the animals examined was $10.77 \%$. The prevalence was significantly higher $(\mathrm{P}<0.05)$ in Red Bororo $(\mathrm{RB})$ breed than others. In all the animals with impaction, the garbage recovered ranged in size from $2.35-7.96 \mathrm{~kg}$ and were composed of twine ropes, cloth, rubber, jute bags, leather, sand and pebbles and polythene materials with non- biodegradable polythene materials being the most prominent. Table 2 shows the sex distribution in relation to prevalence of rumen impaction. More females (57.2\%)

Table 2 - Effect of sex on the prevalence of rumen impaction in cattle examined.

\begin{tabular}{lcc}
\hline \multicolumn{1}{c}{ Sex of Cattle } & Number examined (\%) & $\begin{array}{l}\text { Number (\%) } \\
\text { with Rumen } \\
\text { Impaction }\end{array}$ \\
\hline Male & $1296(42.76)$ & $101(3.08)$ \\
Female & $7735(57.24)$ & $226(6.92)$ \\
TOTAL & $\mathbf{3 0 3 1 ( 1 0 0 )}$ & $\mathbf{3 2 7}(\mathbf{1 0 . 8 )}$ \\
\hline
\end{tabular}


Table 3 - Effect of age on the prevalence of rumen impaction in cattle examined.

\begin{tabular}{lllll}
\hline Age of Cattle & \multicolumn{2}{l}{ Cattle Examined } & \multicolumn{2}{l}{ Cattle with Rumen Impaction } \\
& Number & (\%) & Number & (\%) \\
\hline Below & 682 & 22.50 & 29 & 8.90 \\
2-3 years & 1178 & 38.90 & 96 & 29.30 \\
3-4 years & 606 & 20.00 & 98 & 30.00 \\
Above 4 years & 565 & 18.60 & 104 & 31.80 \\
TOTAL & 3031 & 100.00 & 327 & 100 \\
\hline
\end{tabular}

than males $(42.8 \%)$ were slaughtered. The prevalence of rumen impaction was significantly higher $(\mathrm{P}<0.05)$ in females than males.

The age distribution of animals examined as shown in Table 3 revealed that majority of the animals slaughtered were less than 3 years of age, however, the prevalence of rumen impaction was significantly higher $(\mathrm{P}<0.05)$ in older than younger animals. Total serum protein levels of cattle with rumen impaction was significantly low $(5.74 \pm 1.35)$ as compared to reference value of 7.55 \pm 2.50 (Akerejola et al, 1980)-(Table 4).

\section{Discussion}

The present study has shown that different breeds of cattle are slaughtered in Ibadan, with Sokoto Gudali accounting for $32 \%$ of all breeds examined. This finding is probably due to consumer preference for the breed noted for fast growth and good carcass quality. More females were slaughtered than males. This finding agrees with that of Remi-Adewumi et al (2004) in sheep and goat and may be suggestive of a declining livestock productivity and an indicator of a negative growth in the indigenous livestock industry. The observed poor body condition and carcass quality of slaughtered animals in this study may be a direct consequence of poor

Table 4 -Serum protein and phosphorus levels in cattle with rumen impaction

\begin{tabular}{lccc}
\hline Parameter & Number of Samples & Mean \pm SD & $\begin{array}{l}\text { Reference } \\
\text { value }\end{array}$ \\
\hline $\begin{array}{l}\text { Phosphorus } \\
\text { (mg / dl) }\end{array}$ & 327 & $2.37 \pm 1.23$ & $5.74 \pm 1.45$ \\
$\begin{array}{l}\text { Total protein } \\
\text { (mg / dl) }\end{array}$ & 327 & $5.74 \pm 1.35$ & $7.55 \pm 2.50$ \\
\hline
\end{tabular}


husbandry practices by Pastoralists who rarely supplement for nutritional inadequacies especially during the dry season.

Prevalence of $10.77 \%$ rumen impaction in the study is higher than previously reported by Abdulahi et al (1984) and RemiAdewumi et al (2004). This finding also corroborate our observation with regard to the increase in the number of cases presented for laparorumenotomy in our Veterinary Teaching Hospital within the same period. While the condition is generally believed to be attributed to lack of ability to discriminate against foreign body among ruminants (Blood et al., 1983), it is our opinion that the widespread use of polythene material in rural and urban areas and lack of proper legislation on waste disposal, play a significant role in the aetiopathogenesis of the condition and may probably be responsible for the higher prevalence reported in the study.

The higher prevalence of rumen impaction in older animals than younger ones agrees with the reports of Abdulahi (1984) and Remi-Adewumi et al (2004) and may probably be attributed to the slow, progressive mechanism of development of the condition. Females have a significantly $(\mathrm{P}<0.05)$ higher prevalence of rumen impaction than males. This also agrees with the report of Sanni et al.,(1995) and seems to suggest that females are relatively more sensitive to some of the aetiopathogenic factors involved in the establishment of the condition. Russel (1978) and Sharma and Ranker (1978), attributed those factors to the extra demands of reproduction.

The significantly low serum protein and phosphorus levels in animals with rumen impaction suggest the probable involvement of malnutrition and mineral inadequacies as risk factors. Our investigation is the first attempt to determine and document the probable role of malnutrition and mineral deficiency in the aetiopathogenesis of the condition and thus corroborate the observations of previous reports (Baker, 1979; Imreh 1982; Akinrinmade et al, 1988; Sanni et al, 1988; Remi-Adewumi et al 2004).

Although the result of our investigation have shown that age, sex, protein malnutrition and deficiency of phosphorus are probable risk factors in the animals with rumen impaction with non-biodegradable materials, the precise aetiopathogenesis is yet to be fully comprehended. There is however a convergence of opinion on the part of previous and present researchers that inadequate nutrition especially during the dry season, bad husbandry practices typified by uncontrolled movement of livestock into urban and sub - urban areas and vitamin/mineral deficiencies often associated with perverted appetite, play a major role in the aetiopathogenesis of the condition in ruminant livestock in Nigeria. This opinion is further strengthened by the observed similarity in gross appearance and macroscopic compositions of impacted materials in affected animals. The exact role of vitamins and other minerals especially trace elements deficiencies in the establishment of the condition are yet to be ascertained, as they were not determined in the present and previous studies. Further studies would be necessary to evaluate their role as risk factors.

The economic loss due to rumen impaction and its associated fatalities, loss of body weight and productivity is yet to be quantified and fully appreciated and may continue to pose a great threat to efforts at developing the indigenous livestock industry in Nigeria. 
References

Abdullahi, U. S., Mohammed, G. S. A. and Mshelia, T.A. 1984. Impaction of the rumen with indigestive garbage in cattle and sheep reared within urban and sub-urban environment. Nig. Vet. J., 13: 89-95.

Akerejola, O. O., Umunna, N. N. and Dennis, S. M. 1980. Serum biochemical values of cattle in Northern Nigeria. Nig. Vet.J. 9(1): 26 31.

Akinrinmade, J. F., Akusu, M. O. and Oni, S.O. 1998. Gastrointestinal foreign body syndrome in sheep - A case report. Nig. J. Anim. Prod., 15: $145-148$.

Baker, J. S. 1997. Abomasal obstruction and related obstructions of the forestomach in cattle. J. Am. Vet. Med.Ass. 195(12): 1250-1253.

Blood, D. C., Radostitis, O. M. and Henderson, J. A. 1983. Veterinary Medicine. ELSB Bailliere, Tindall and Cox, London $6^{\text {th }}$ Edition. Page 132 203.

Corad, J. H., McDowell, L. R. and Laosi, J. K. 1982. Mineral Deficiencies and Toxicities for Grazing Ruminants in the Tropics. In: Animal Production in the Tropics page $73-112$. Praeger Publishers, NY, USA.

EIsa, A. T., Garba, H. S. and Daneji, A. I. 1993. Indications, causes and complications of numenotony in small ruminants in Sokoto, Nigeria. Nig. Vet. J., $3: 45-49$.

Grumberg, W., Dawn, E., Morning, J., Berger, A, and Constable, P 2006. Effect of continuous intravenous administration of $50 \%$ dextrose solution on phosphorus homeostasis in dairy cows. J. Am. Vet. Med. Ass. 229(3): 413-420.

Imrem, H. Y. 1982. Changes in blood calcium and phosphorus concentrations in cattle with foreign body syndrome. Veterinary Fakultesi Diergisi, Ankara Universities 29: 71 . 78

Langhans, W, Scharret, E 1986. Pathophysiology of Inappetence. J.Am Vet. Med. Ass. 33: 401-413.

McDonald, P., Edward, R. A., Greenhalgh, J. F. D and Morgan, C. A. 1995. Animal Nutrition. $5^{\text {th }}$ edition, Longman, United Kingdom.

McDowell, L. R. 1985. Nutrition of grazing ruminants in warm climates. Academic Press Inc. San Diego. CA.

Otesile, E. B. and Akpokodje, J. U. 1999. Fatal Ruminal Impaction in West African Dwarf Goat and Sheep. Tropical Veterinarian 9: 9-11.

Radostitis, O. M., Blood, D. C. and Gropy C. C. 1997. Veterinary Medicine. A textbook of the diseases of cattle, sheep, pigs, goats and horses. ELBS Bailliere Tindall, London. $8^{\text {th }}$ edition.

Remi Adewumi, B. D., Gyang, E. O. and Osinowo, A. O. 2004. Abattoir survey of foreign body rumen impaction in small animals. Nig. Vet. J. 25 (2) 32 38.

Russel, A. J. F. 1978. The nutrition of pregnant ewe. In: Management and Diseases of Sheep. Paper presented at a British council speech courses. Edinburg, $5^{\text {th }}-7^{\text {th }}$ March, pages 238 239.

Sanni, B. D; Gyang, E. O. and Osinowo, O. A. 1998. Polythene bag induced rumen impaction in small Ruminants : An environment hazard. In proceedings of the Silver Anniversary Conference of the Nigeria Society for Animal Production. Abeokuta pages 97-9.

Sharma, K. B. and Ranker, A. K. 1998. 
Foreign body syndrome in goats - A case report of 5 cases. India Vet $J 55$ (5): $413-414$.

Sisson, E and Grossman, O 1995. The Anatomy of the Domestic Animals. W. B. Saunders Company, Philadelphia. $5^{\text {th }}$ Edition. 